\title{
Miningo
}

http://dx.doi.org/10.1590/0370-44672017710060

\author{
Giuseppe Pintaude \\ Professor \\ Universidade Tecnológica Federal do Paraná - UTFPR \\ Curitiba - Paraná - Brasil \\ giuseppepintaude@gmail.com \\ Nilson Mar Bartalini \\ Mestre em Engenharia Mineral \\ Supervisor Regional da Clariant S/A - CMS \\ São Paulo - São Paulo - Brasil \\ nilson.bartalini@clariant.com
}

\section{Revisiting gouging abrasion test for jaw crushers}

\begin{abstract}
The use of a gouging abrasion test to evaluate the wear of jaw crushers is revised in terms of its procedures, considering the effects of the most significant variables, such as the minimum amount of crushed material and the minimum opening between the jaws during the crushing cycle (minimum discharge aperture). A correlation between the work hardening of jaws and the amount of crushed material is presented. The wear of stationary and movable jaws is compared, being the results dependent on the jaw's material and the discharge aperture. The abrasiveness of several rocks was evaluated, showing a good correlation with their Mohs hardness.
\end{abstract}

Keywords: jaw crusher; gouging abrasion test; work hardening; abrasiveness.

Before these publications, the Climax Molybdenum Company presented significant investigations for the interpretation of results obtained in tests to estimate the wear of jaw crushers (Borik and Sponseller, 1971a; Borik and Sponseller, 1971b).

The contributions of these research groups promoted a consolidation of an ASTM standard for a gouging abrasion test using jaw crushers, edited for first time in 1997 and reapproved in 2002, 2007 and finally in 2013.

More recently, a research group from Chalmers University (Lindqvist and Evertsson, 2003) studied the wear of jaw crushers, but their goal was to transfer a developed wear model for cone crushers.

As austenitic manganese steel is widely used as material to manufacture jaws. Some recent investigations de-

was evaluated for different amounts of crushed material, to establish a minimum of cycles to measure wear in the steady-state regime. The procedures to determine hardness were described by Pintaude et al. (2003). In the second set, two materials were used for this, a high silicon (2Cr-1.5Si-0.5Mo) and a manganese cast steel, evaluating the effect of the closed side set (CSS) - the minimum opening between the jaws served attention for the microstructural aspects of this alloy and its performance being tested in terms of wear (Silva, 2004; Olawale et al., 2013; Magdaluyo et al., 2016). Considering the wear performance of a wide range of materials and hardfacing deposits during gouging abrasion test, the findings described by Llewellyn et al. (2006) can be considered a very useful guide.

In Brazil, academic studies were conducted at the University of São Paulo, being the first one a thesis (Siriani, 1973), whose detailed data was extracted directly from mining operations, and two Master's Dissertations (Pintaúde, 1998; Bartalini, 1999), which used a small machine, a lab prototype of a jaw crusher. This article is a historical summary of the main contributions given by these researches for understanding wear of jaw crushers.

\section{Materials and methods}

performed using a small lab jaw crusher, with sample dimensions of $135 \mathrm{~mm}$ X $75 \mathrm{~mm}$ X $25 \mathrm{~mm}$. For the first and second ones, the same crushed material, granite with particle size between 1" and 3/4" was used. Details of its mineralogical characterization can be found in Pintaude et al. (2001). In these experiments, the work hardening of worn surfaces 


\begin{tabular}{c|c|c|c|c} 
Set & Crushed material & Jaw material & CSS, mm & Objective \\
\hline $1^{\text {st }}$ & Granite & High Si cast steel & $3.2^{*}$ & $\begin{array}{c}\text { Evaluation of minimum } \\
\text { amount of crushed } \\
\text { material and work } \\
\text { hardening of stationary jaw }\end{array}$ \\
\hline $2^{\text {nd }}$ & Granite & High Si cast steel & $0,3.2^{*}$ & \begin{tabular}{c} 
Evaluate the effect \\
of CSS, compare materials, \\
\cline { 3 - 4 }
\end{tabular} \\
\cline { 3 - 4 } & High Mn cast steel & $1.8,4.5$, and 7.2 & $\begin{array}{c}\text { Evaluate the } \\
\text { abrasiveness of rocks }\end{array}$ \\
\hline $3^{\text {rd }}$ & Eight rocks** & High Mn cast steel & 4.5 & \\
\hline
\end{tabular}

*recommended by ASTM G81-97(2013).

**basalt, diabase, quartzite and five granites.

\section{Results}

\section{First set of experiments}

Figure 1 shows the wear of the stationary jaw manufactured in high Si cast

steel as a function of the crushing batches. In the same Figure, the microhardness of

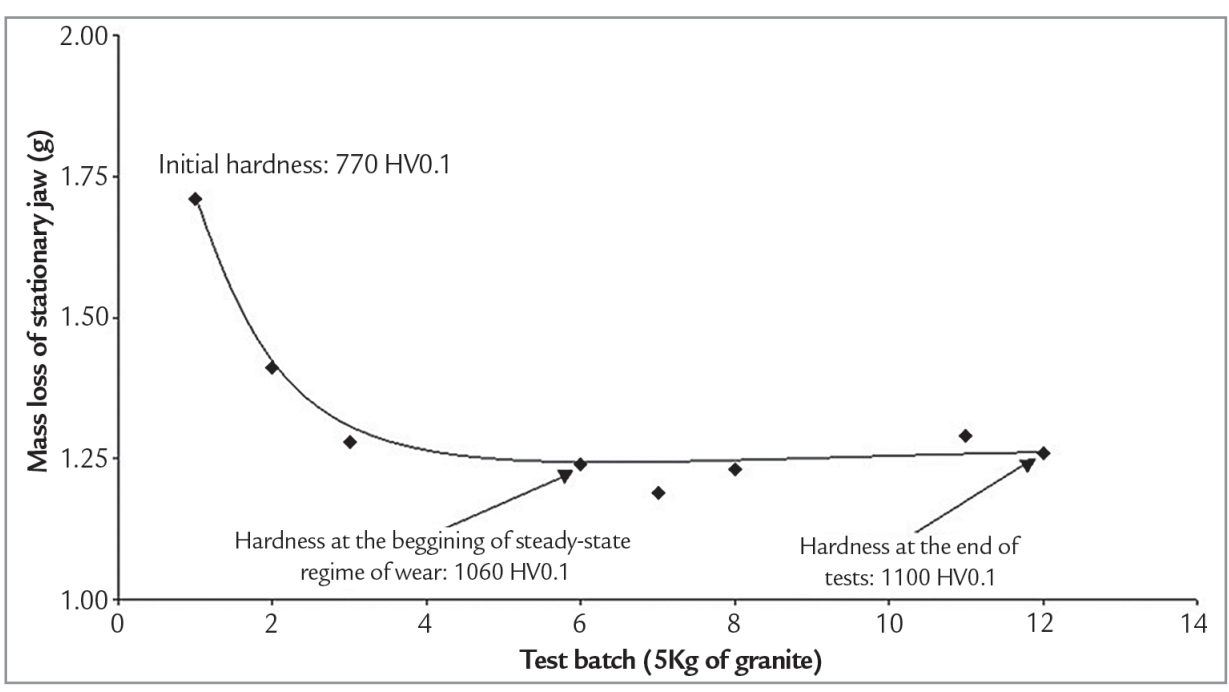

One can clearly observe that the wear reached a steady-state regime when the values of microhardnessa at the worn surfaces did not present any variation. In this fashion, the description made by Blickensderfer et al. (1985) for a minimum crushed material to reach a steady-state regime of wear in a similar lab equipment can be considered as suitable. They recommended a minimum of $90 \mathrm{~kg}$, while ASTM G81-97(2013) requires $900 \mathrm{~kg}$, but in this case the dimensions of the equipment are higher.

The extension of plastic defor-
Table 1

Main parameters used in each set of experiments. each step is presented, and was used to evaluate the work hardening.
Figure 1

Variation of mass loss (g) a stationary jaw (high Si cast steel) for different crushing cycles of granite, using CSS $=3.2 \mathrm{~mm}$. Values of superficial microhardness (HV0.1) are shown.

mation was also evaluated, as shown in Figure 2. One can observe that the level of deformation is sufficient to alter up to $1 \mathrm{~mm}$ below the worn surface. Similar results were reported by Borik and Sponseller (1971) for austenitic manganese steel.

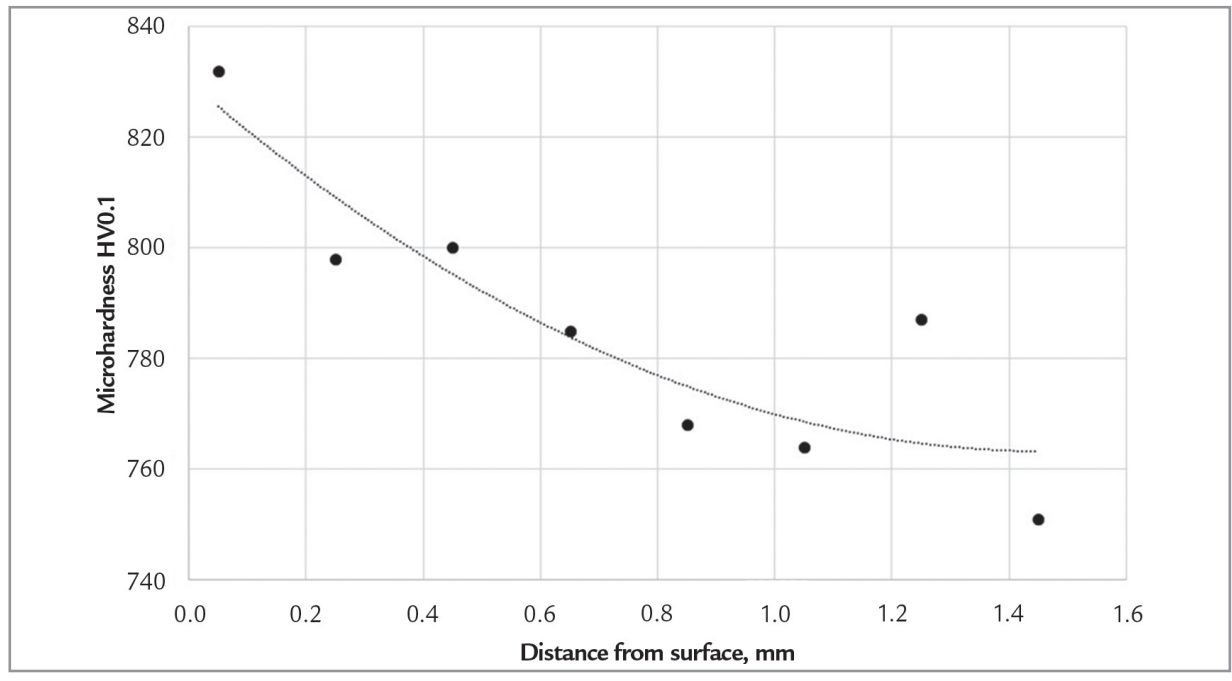

Figure 2

Extension of plastic deformation of a stationary jaw (high Si cast steel) after tests crushing granite for CSS $=3.2 \mathrm{~mm}$. 


\section{Second set of experiments}

Figure 3 shows the variation of wear rates in terms of CCS $(\mathrm{mm})$. In a general way, the smaller the CSS, the higher the wear. This is an expected result (Borik and Sponseller, 1971), since the compression forces increase with the reduction of discharge aperture.

In addition to the effect of CSS on the wear rates, other observations can be discussed from this set of experiments. The first one is related to the tested materials, which were dependent on

Figure 3

Variation of wear $(\mathrm{g} / \mathrm{t})$ in terms of CSS (mm), crushing granite.

\section{Third set of experiments}

Figure 4 shows the relationship between the wear rates and the Mohs hardness of several rocks, tested under the same

Figure 4

Variation of wear rate

(high Mn cast steel) in terms of Mohs hardness of crushed rocks. (CSS $=4.5 \mathrm{~mm})$.

\section{Conclusions}

This article summarizes results obtained in a gouging abrasion test obtained with a lab jaw crusher machine. The following conclusions can be presented:

- The minimum amount of the position of jaw. High Mn cast steel performed much better when a stationary jaw is considered, but for a movable one, the high Si cast steel presented a better behavior in terms of wear resistance. This difference explains, from the numerical point of view, the wear of stationary jaws in relation to those determined for the movables, which was much superior in case of the experiments conducted using high Si cast steel.

The wear of a stationary jaw tends to be increasingly higher than that determined for movable side as the CSS diminished. In an indirect way, one can conclude that the increase of compression forces can cause an increase on the gouging action on the stationary jaw, but this extension will depend on the tested material. More accurate conclusions with this issue could be treated in future investigations, helping to select in a better way for the materials with different jaws.

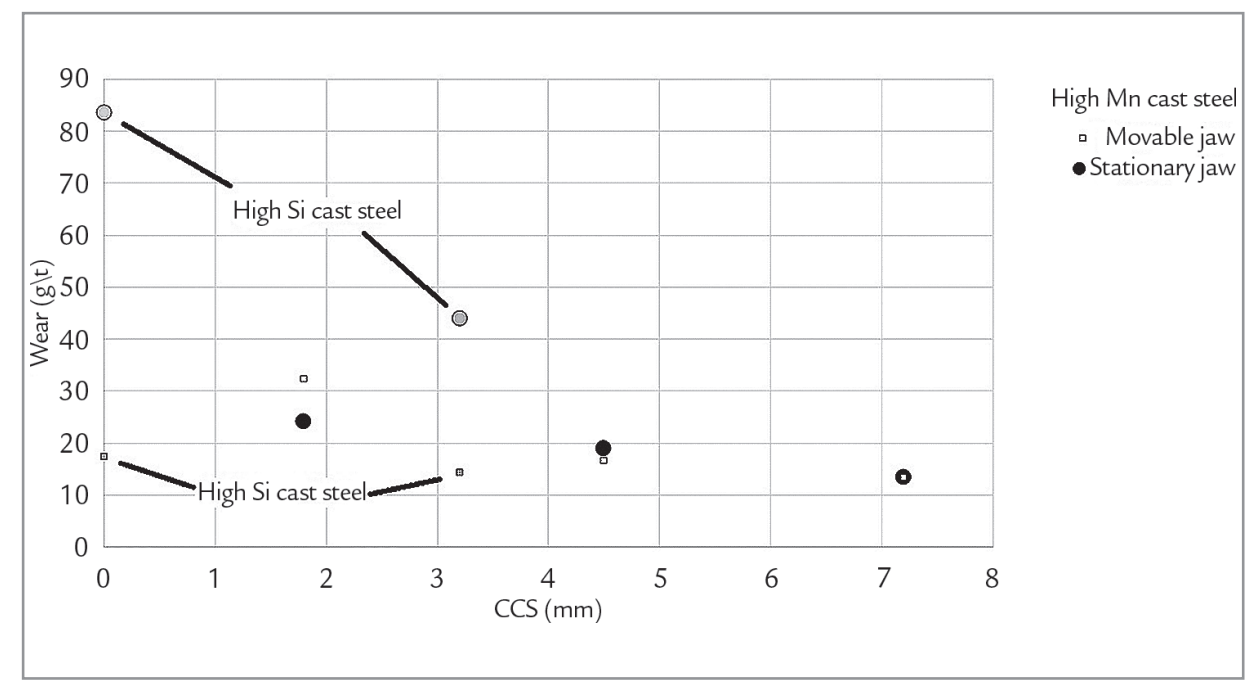

conditions. Good correlations are found (R2 0.85), being the increase of hardness, consequently the abrasiveness, attributed to the increase of quartz content. This relationship was pointed out previously by Siriani (1973) and confirmed here in another way.

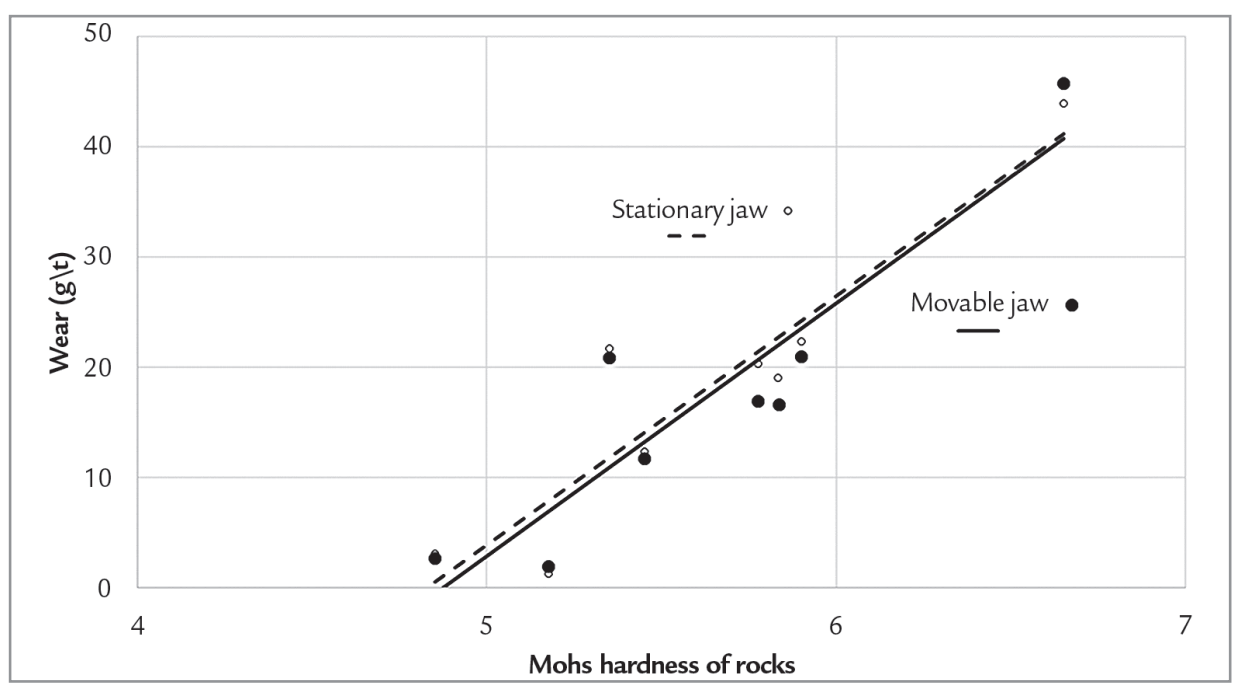

crushed material to achieve the steadystate regime of wear was closely related to the work hardening of the worn surface;

- The wear rate of jaws increases for smaller close sided sets, but this variation depends on the material of the jaws; and

- A gouging abrasion test can be used to verify the abrasiveness of rocks, and the quartz content is an important factor for this issue. 


\section{Acknowledgments}

Authors acknowledge Embu S.A. for supplying rocks for lab tests. Special thanks are to the advisors, professors A.

Sinatora, D. K. Tanaka and F. Fujimura.

\section{References}

ALDRICH, C. Consumption of steel grinding media in mills-A review. Minerals Engineering, v. 49, p. 77-91, 2013

ASTM G81-97a(2013), Standard Test Method for Jaw Crusher Gouging Abrasion Test, ASTM International, West Conshohocken, PA, 2013, www.astm.org

BARTALINI, N. M. Desgaste abrasivo em britadores de mandíbulas. São Paulo: Escola Politécnica da Universidade de São Paulo, 1999. 158 p. (Dissertação de Mestrado em Engenharia de Minas).

BLICKENSDERFER, R., MADSEN, B. W., TYLCZAK, J. H. Comparison of several types of abrasive wear tests. In: INT. CONF. ON WEAR OF MATERIALS, 1985. Vancouver. Proc. of Wear of Materials 1985. ASME, 1985. v. 1, p. 313-323, 1985.

BORIK, F., SCHOLZ, W. G. Gouging abrasion test for material used in ore and rock crushing. Part 2: effect of metallurgical variables on gouging wear. Journal of Materials, v. 6, n. 3, p. 590-605, 1971.

BORIK, F., SPONSELLER, D. L. Gouging abrasion test for material used in ore and rock crushing. Part 1: description of the test. Journal of Materials, v. 6, n. 3, p. 576-589, 1971.

HAWK, J. A. et al. Laboratory abrasive wear tests: investigation of test methods and alloy correlation. Wear, v. 225, p. 1031-1042, 1999.

LINDQVIST, M., EVERTSSON, C. M. Liner wear in jaw crushers. Minerals Engineering, v. 16, n. 1, p. 1-12, 2003.

LLEWELLYN, R. J., HALL, R. A., DU, J. R. Assessment of materials for gouging abrasion applications. In: AUSTRIB 2006, 2006. Brisbane. Proc. of Austrib: National Reseach Council, 2006. v.1, p. 1-8.

MAGDALUYO Jr, E. R., AUSA, M. S., TINIO, R. J. Effect of titanium on gouging abrasion behavior and hardness of austenitic manganese steel. In: Transactions on Engineering Technologies. Springer Singapore, 2016. p. 73-81.

OLAWALE, J. O., IBITOYE, S. A., SHITTU, M. D. Work hardening behaviour and microstructural analysis of failed austenitic manganese steel crusher jaws. Materials Research, v. 16, n. 6, p. 1274-1281, 2013.

PINTAÚDE, G. Estudo do regime transiente em desgaste abrasivo: ensaios em britador de mandíbulas. São Paulo: Escola Politécnica da Universidade de São Paulo, 1998. 126 p. (Dissertação de Mestrado em Engenharia Mecânica).

PINTAUDE, G. et al. The particle size effect on abrasive wear of high-chromium white cast iron mill balls. Wear, v. 250, n. 1, p. 66-70, 2001.

PINTAUDE, G., TANAKA, D. K., SINATORA, A. The effects of abrasive particle size on the sliding friction coefficient of steel using a spiral pin-on-disk apparatus. Wear, v. 255, n. 1, p. 55-59, 2003.

RADZISZEWSKI, P. Exploring total media wear. Minerals Engineering, v. 15, n. 12, p. 1073-1087, 2002.

SARE, I. R. et al. The determination of gouging abrasion resistance by jaw crusher tests. In: CONFERENCE ON LUBRICATION, FRICTION AND WEAR IN ENGINEERING 1980, Melbourne: Preprints of Papers, Institution of Engineers, Australia, 1980. p. 94.

SARE, I. R., ARNOLD, B. K. Gouging abrasion of wear-resistant alloy white cast irons. Wear, v. 131, n. 1, p. 15-37, 1989.

SARE, I. R., CONSTANTINE, A. G. Design and analysis of jaw crusher gouging abrasion tests. Journal of Testing and Evaluation, v. 19, n. 2, p. 115-122, 1991.

SARE, I. R., CONSTANTINE, A. G. Development of methodologies for the evaluation of wear-resistant materials for the mineral industry. Wear, v. 203, p. 671-678, 1997.

SARE, IR S., ARNOLD, B. K. The effect of heat treatment on the gouging abrasion resistance of alloy white cast irons. Metallurgical and Materials Transactions A, v. 26, n. 2, p. 357-370, 1995.

SILVA, G. N. da. Efeito da substituição do molibdênio pelo nióbio e nióbio- 
-boro em aços Hadfield no desempenho ao desgaste abrasivo. Ouro Preto: Universidade Federal de Ouro Preto, 2004. 122 f. (Dissertação de Mestrado em Engenharia de Materiais).

SIRIANI, F. A. Características gerais de desgaste de mandíbulas em britadores. São Paulo: Escola Politécnica da Universidade de São Paulo, 1973. 281 p. (Tese de Doutorado em Engenharia de Minas).

TYLCZAK, J. H., HAWK, J. A., WILSON, R. D. A comparison of laboratory abrasion and field wear results. Wear, v. 225, p. 1059-1069, 1999.

Received: 28 March 2017 - Accepted: 25 September 2017. 